\title{
PEMAKNAAN PESAN PADA UPACARA RITUAL TABOT (STUDI PADA SIMBOL-SIMBOL KEBUDAYAAN TABOT DI PROVINSI BENGKULU)
}

Oleh :

\author{
LINDA ASTUTI \\ Dosen Prodi Ilmu Komunikasi FISIP Universitas Ratu Samban Bengkulu Utara
}

\begin{abstract}
This study aimed to determine the stages in the Tabot ceremony, found out the meaning of the messages at each of these stages, and also looked for the symbols meaning in the ceremony. This research was expected to provide contributions to the development of Communication Sciences, particularly those related to the symbolic meaning of the message as well as verbal and nonverbal communication. This research used descriptive qualitative method. The results showed that the Tabot ceremony in Bengkulu was a hereditary tradition which carried out annually and was taken as an asset to the area. The ceremony was conducted by nine ritual, where each ritual laden with messages and meanings that carries meaning and tells a history or story.
\end{abstract}

\section{Keywords: the meaning of the message, culture symbols, tabot ceremony}

\section{PENDAHULUAN}

Tradisi tabot merupakan salah satu upacara tradisional di Kota Bengkulu. Tabot dirayakan dari tanggal 1 sampai dengan tanggal 10 Muharam pada setiap tahunnya dengan tujuan untuk memperingati gugurnya Hasan dan Husen cucu Nabi Muhammad SAW oleh keluarga Yazid dan kaum Syiah, dalam perperangan di Karbala pada tahun 61 Hijriah. Pada perayaan TABOT tersebut dilaksanakan berbagai pameran serta lomba ikan-ikan, telong-telong serta kesenian lainnya yang didikuti oleh kelompok-kelompok kesenian yang ada di Provinsi Bengkulu sehingga menjadi ajang hiburan rakyat dan menjadi kalender wisata tahunan. Maksud dan tujuan penyelenggaraan festival Tabot antara lain adalah untuk memperingati wafatnya cucu Nabi Muhammad SAW yakni Husein dan bin Abi Thalib yang terbunuh dipadang karbal, Irak oleh Yasid bin Muawiyyah. Namun, sekaligus untuk melestarikan budaya masyarakat Bengkulu, sebagai bentuk penghormatan terhadap ketokohan Husein bin Abi Thalib.

Festival Tabot di Bengkulu juga sebagai kegiatan menyambut dan memeriahkan tahun baru Islam. Juga ada upaya menjadikan acara Budaya Tabot sebagai objek wisata budaya daerah untuk dikunjungi dan dilihat oleh selurah masyarakat dan menjadi kebanggaan Bengkulu. Festival tabot telah berlangsung selama bertahun-tahun di Benngkulu, dan sejak masa silam menjadi tradisi bagi masyarakat disana, serta "keharusan" yang tak boleh ditinggalkan untuk dilaksanakan para keturunan Tabot setiap 1-10 Muharram tahun Hijriah. Festival Tabot semula adalah tradisi ritual di Bengkulu, namun kini telah berkembang menjadi suatu kebutuhan masyarakat luas, seperti berbagai tradisi yang telah lama berlangsung di seluruh penjuru Nusantara.

Dalam ritual Tabot ada sembilan langkah yaitu: Mengambik tanah, Duduk penja (mencuci jari-jari), Menjara, Meradai (mengumpulkan dana), Arak Penja (mengarak jari-jari), Arak Serban (mengarak surban), Gam (tenang berkabung), Arak Gedang (taptu akbar), dan Tabot Terbuang. Berbagai syarat atau langkah dalam ritual upacara Tabot sangat menarik untuk di teliti karena pemaknaan 
pesan yang terkandung di dalamnya berhubungan dengan nilai-nilai yang ada dalam kehidupan sosial masyarakat.

Setiap tahapan mempunyai makna tersendiri yang dipahami oleh masyrakat melalui simbol-simbol yang ada pada tradisi upacara Tabot. Dalam upacara ritual Tabot banyak terdapat unsur-unsur berupa simbol baik dalam tata cara maupun aturannya. Bagi penulis simbol tersebut merupakan suatu hal yang unik dan menarik untuk diteliti karena sebenarnya simbol-simbol tersebut memiliki kandungan makna yang begitu dalam. Oleh karena itu menjadi menarik untuk melihat lebih jauh proses simbolisasi berlangsung di masyarakat terhadap pemaknaan yang diberikan pada upacara Tabot, serta bagaimana pemaknaan simbol-simbol yang terkandung pada ritual upacara Tabot.

\section{METODE PENELITIAN}

Metode penelitian ini menggunakan pendekatan kualitatif. Pendekatan ini lebih bersifat interpretatif subjektif yang menekankan pada penciptaan makna, artinya individu-individu melakukan pemeknaan terhadap segala prilaku yang terjadi. Bogdan dan Taylor dalam Moleong (2001: 1) penelitian kualitatif adalah penelitian yang menghasilkan data deskriptif berupa kata-kata tertulis atau lisan dari orang-orang dan perilaku yang dapat diamati.

\section{Subjek Penelitian}

Subjek penelitian ini adalah Kerukunan Keluarga Tabot (KKT) yang diasumsikan berasal dari kelompok keluarga Tabot yang mewarisi dan menjaga serta bertanggung jawab atas penyelenggaraan upacara Tabot. Informan pokok dalam penelitian ini berasal dari masyarakat yang terlibat langsung dalam kegiatan tersebut, sementara informan ahli dalam penelitian ini, peneliti mengambil pimpinan acara.

\section{Teknik Pengumpulan Data}

Metode pengumpulan data yang peneliti lakukan dalam penelitian ini adalah melalui kegiatan observasi langsung, wawancara kepada pihak terkait dan melakukan pengumpulkan data yang telah jadi ataupun telah diolah oleh pihak lain serta mengambil dokumentasi yang berkaitan dengan upacara.

\section{TEKNIK ANALISIS DATA}

Analisis data dalam penelitian ini menggunakan pendekatan analisis interpretatif kualitatif, dimana peneliti akan memaknai, menguraikan dan membahas secara mendalam terhadap gejala, peristiwa atau masalah-masalah aktual yang ada pada saat penelitian dilakukan. Analisis data dalam penelitian kualitatif dilakukan pada saat pengumpulan data berlangsung, dan setelah selesai pengumpulan data dalam periode tertentu.

Selain itu, analisis data berlangsung bersamaan dengan proses pengumpulan data melalui 3 tahapan yang dilakuakan secara simultan yaitu reduksi data, penyajian data dan verifikasi data (pengambilan kesimpulan).

\section{HASIL PENELITIAN Pemaknaan Pesan}

Pesan (Effendy, 2003) adalah informasi yang disampaikan dengan menggunakan lambang (simbol). Dalam komunikasi pesan terdiri dari dua aspek, pertama isi pesan (content of the messege), kedua lambang (simbol). Kongkretnya isi pesan adalah pikiran atau perasaan, lambang adalah bahasa. Dalam situasisituasi komunikasi tertentu lambanglambang yang digunakan dapat berupa kial (gesture), yakni gerak anggota tubuh, gambar, warna, dan lain sebagainya. Komunikasi akan berjalan efektif apabila terjadi kesamaan makna antara komunikator sebagai penyampai pesan dan komunikan sebagai penerima pesan. Pemaknaan pesan dalam penelitian ini dimaksudnya adalah bagaimana masyarakat 
dapat mengerti maksud dan tujuan dari pesan yang ada melalui simbol-simbol pada tradisi.

\section{Ritual}

Kata ritual selalu diidentikan dengan habit (kebiasaan) atau rutinitas. Rothenbuhler (1998) menguraikan bahwa, "ritual is the voluntary performance of appropriately patterned behavior to symbolically effect or participate in the serious life". Sementara itu, Couldry memahami ritual sebagai suatu habitual action (aksi turun-temurun),aksi formal dan juga mengandung nilai-nilai transendental. Mencerminkan pandangan-pandangan tersebut, dipahami bahwa ritual berkaitan dengan pertunjukan secara suka rela yang dilakukan masyarakat secara turun-temurun (berdasarkan kebiasaan) menyangkut prilaku yang terpola. Pertunjukan tersebut bertujuan mensimbolissasi suatu pengaruh dalam kehidupan kemasyarakatan. Lebih jelas, Rohtenbuhler menguraikan beberapa karakteristik dari ritual itu sendiri sebagai berikut:

\section{Ritual sebagai aksi}

Ritual merupakan aksi dan bukan hanya sekedar pemikiran atau konsep semata. Dalam kehidupan sehari-hari, mitos adalah salah satu rasionalisasi dari aktifitas ritual. Dengan demikian ritual dipandang sebagai suatu bentuk aksi tidak saja sebagai salah satu cara berpikir. Ritualpun merupakan sesuatu hal dimana orang mempraktekkannya dan tidak saja dipendam dalam benak

\section{Performance (pertunjukan)}

Ritual dipertunjukan sebagai suatu bentuk komunikasi tingkat tinggi yang ditandai dengan keindahan (estetika), dirancang dalam suatu cara yang khusus serta memperagakan sesuatu kepada khalayaknya. Karena menekankan pada unsur estetika, pertunjukan ritual mengandung dua karakteristik. Pertama, ritual tidak perna diciptakan dalam momentum aksi itu sendiri. Sebaliknya, ritual selalu merupakan aksi yang didasarkan pada konsepsi-konsepsi yang ada sebelumnya, kedua, ritual selalu merupakan pertunjukan untuk orang lain. Pertunjukan tersebut dimaksudkan untuk memperagakan kompetensi komunikasi kepada khalayak.

\section{Kesadaran dan kerelaan}

Ritual selalu dilakukan secara sadar dan karenanya bersifat kerelaan. Dalam hal ritual-ritual yang bersifat special event, orang secara sadar untuk terlibat baik sebagai pelaku pertunjukan maupun sebagai penonton. Biasanya untuk terlibat dalam suatu ritual adalah pilihan. Orang dapat memilih untuk terlibat ataupun sebalikny tidak terlibat.

\section{Irrational}

Seringkali ritual dipandang sebagai tindakan yang irrational (tidak masuk akal) karena tidak banyak bermanfaat bagi tujuan-tujuan yang spesifik. Parsons lalu berkesimpulan bahwa pelaksanaan ritualritual seringkali diasosiasikan dengan praktek magic. Dalam konteks yang demikian, ritual dipandang tidak masuk akal. Namun, pendapat di atas dibantah oleh Wallace yang menyatakan kalau ternyata tidak semua ritual bersifat irrational dan noninstrumental dalam segala hal. Dalam pandangan Wallace, ritual magic sekalipun dipakai untuk mempertunjukan fungsi-fungsi sosial yang lain seperti mengurangi keragu-raguan, bagaimana menghasilkan kesepakatan, dan bahkan bisa menginspirasi orang lain untuk bertindak.

\section{Ritual bukanlah sekedar Rekreasi}

Berbagai ritual yang dipraktekkan tidaklah sekedar kegiatan rekreasi. Walaupun sering terjadi perayaan melalui ritual, namun ritual bukan saja untuk kegiatan hura-hura atau bersenang-senang semata. Sesungguhnya ritual merupakan bagian dari kehidupan yang serius (serious life).

\section{Kolektif}

Secara menyeluruh, ritual bukanlah sesuatu yang dilakukan secara individu untuk kepentingan individual dalam caracara yang murni individualistik. Ritual meskipun ditunjukan secara pribadi, tetapi 
selalu terdapat struktur secara sosial didalamnya. Misalnya saja : sistem bahasa dan tanda yang digunakan, tradisi, dan moral, selain itu, ritual juga beroryentasi pada suatu kelompok dan umumnya ditampilkan dalam situasi-situasi sosial. Bahkan, ritual tidak saja ditampilkan dalam situasi sosial dan diatur oleh fenomena sosial melainkan ritual juga memiliki makna-makna sosial. Karena itulah Leach mengatakan bahwa ritual selalu merujuk pada relationship (relasi) dan posisi sosial. Ritual pun merupakan salah satu cara dalam mengukur dan menyampaikan maksud-maksud yang berorientasi sosial.

\section{Ekspresi dari Relasi Sosial}

Ritual meliputi penggunaan modelmodel perilaku yang mengekspresikan relasi sosial. Bentuk-bentuk dari aksi ritual merupakan simbol-simbol daro relefaen atau petunjuk dari relasi sosial, perintahperintah, dan institusi-institusi sosial dimana ritual itu dipertunjukan.

\section{Subjunctive dan Not Indicative}

Ritual selalu terjadi dalam modus pengandaian. Hal mana bahwa ritual seringkali berkaitan dengan berbagai kemungkinan seperti bagaimana sebaiknya/seharusnya, dan bukanlah apa menyangkut sesuatu yang sedang terjadi. Sebagaimana Handelman menjelaskan, ritual-ritual boleh saja dipakai sebagai model atau menghadirkan ide berkaitan dengan berbagai peraturan sosial, namun ritual tidak perna mencerminkan status quo secara struktual.

\section{Efektifitas simbol-simbol}

Simbol-simbol dalam suatu ritual sangat efektif dan powerful. Kekuatan dari simbol-simbol ritual ini secara jelasnya nampak dalam bentuk ritus.simbol-simbol ritual selalu berperan dalam semua bentuk ritual. Bahkan, ketika terjadi tranformasi sosial yang tidak menampilkan maksud secara eksplisit dari suatu pertunjukan ritual seperti halnya sebuah lagu, tarian, gerak-gerik tubuh, doa, perjamuan, kebiasaan, dan sebagainya. Simbol-simbol tersebut berfungsi sebagai alat komunikasi.

\section{Condensed Symbol}

Simbol-simbol yang singkat merujuk pada karakteristik dari simbolsimbol ritual yang memiliki makna dan aksi ganda. Karenanya, simbol-simbol yang dipersingkat atau kental (condensed symbol) seringkali membinggungkan (ambiguous) dan sulit bagi pengamat sosial. Misalnya, simbol dapat ditampilkan dalam cara-cara yang berbeda untuk orang-orang yang berbeda tergantung pada kepekaan mereka terhadap perbedaan-perbedaan valensi. Implikasi, simbol-simbol mengandung makna lebih dari biasa.

\section{Ekspresif atau Perilaku Estetika}

Ekspresif adalah salah satu bentuk inti dari ritual dimana mengambil posisi sebagai bagian dari apa yang dilakukan dalam ritual serta bagaimana melakukannya. Ritual juga mempunyai komponen estetika yang mendasar. Banyak dari komponen-komponen estetika tersebut sangat menakjubkan.

\section{Customary Behavior}

Ritual merupakan bentuk-bentuk dari perilaku yang bersifat kebiasaan. Ritual mengandung makna pengulangan sebagaimana delakukan dengan cara yang serupa pada zaman atau era sebelumnya. Artinya, ritual tidaklah dikarangoleh para pelaku. Sebaliknya, ritual merupakan perilaku yang didasarkan menurut kebiasaan atau aturan yang distandarkan. Dengan demikian, perilaku karena kebiasaan ini bersifat imperatif, berkaitan dengan etika, serta perintah sosial.

\section{Regularly Recuring Behavior}

Ritual merupakan perilaku yang dilakukan berulang (repetitive) secara rutin. Banyak ritual yang dilakukan secara terjadwal, dan ditentukan ditentukan mengikuti siklus waktu. Salah satu implikasi penting dari ritual yang terjadi secara berkala ini adalah ia tidak diatur dan didikte oleh situasi yang spesifik, melainkan melalui apa yang dipandang benar.

\section{Komunikasi tanpa informasi}

Sebetulnya ide tentang ritual sebagi suatu komunikasi tanpa informasi 
menekankan bahwa dalam ritual banyak menampilkan atau mengetengahkan pertunjukan ketimbang informasi. Dalam hal-hal tertentu, lebih cenderung mengutamakan penerimaan dari pada perubahan. Sebagaimana diketahui bahwa ada unsur kerelaan dalam ritual. Kemudian aksi untuk terlibat dalam ritual juga pilihan. Karena itu dalam setiap ritual terkandung tidak sedikit sejumlah informasi.

\section{Keramat}

Banyak ahli yang menekankan bahwa ritual adalah aksi yang berkaitan dengan keramat atau sakral. Adapun kriteria dari kesakralan itu adalah menyangkut pola aktifitas atau tindakan dari anggota masyarakat. Contohnya, bagaimana masyarakat menyuguhkan dan memperlakukan obyek-obyek yang dianggap sakral. Tindakan semacam ini mencerminkan suatu tendensi betapa pentingnya suatu benda yang disakralkan tersebut dalam hidup mereka.

Ritual merupakan salah satu cara dalam berkomunikasi. Semua bentuk ritual adalah komunikatif. Ritual selalu merupakan perilaku simbolik dalam situasisituasi sosial. Karena itu ritual selalu merupakan suatu cara untuk menyampaikan sesuatu.

Menyadari ritual adalah salah satu cara dalam berkomunikasi,maka kemudian muncul istilah komunikasi ritual. Istilah komunikasi ritual pertama sekali dicetuskan oleh James W. Carey. Ia menyebutkan bahwa," in a ritual definition, communication is linked to terms such as "sharing,"”"participation,"'”assosiation,"'fell owship,"' and " the posseeion of a common failth." Hal ini berarti, dalam persepektif ritual, komunikasi berkaitan dengan berbagi, partisipasi, perkumpulan/asosiasi, persahabatan, adan kepemilikan akan keyakinan iman yang ada.

Selanjutnya ditambahkan Carey, dalam pandangan ritual, komunikasi tidak secara langsung diarahkan untuk menyebarluaskan pesan dalam suatu ruang, namun lebih kepada pemeliharaan suatu komunitas dalam suatu waktu. Komunikasi yang dibangun juga bukanlah sebagai tindakan untuk memberikan/mengimpartasikan informasi melainkan untuk mereprentasi atau menghadirkan kembali kepercayaankepercayaan bersama.

Pola komunikasi yang dibangun dalam pandangan ritual adalah sacred ceremony (upacara sakral/suci) dimana setiap orang secara bersama-sama bersekutu dan berkumpul (fellowship and communality). Senada dengan hal ini, Radford menambahkan, pola komunikasi dalam persepektif ritual bukanlah si pengirim mengirimkan suatu pesan kepada penerima, namun sebagai upacara suci dimana setiap orang ikut mengembil bagian secara bersama dalam bersekutu dan berkumpul sebagaimana halnya melakukan perjamuan kudus. Dalam pandangan ritual, yang lebih dipentingkan adalah kebersamaan masyarakat dalam melakukan doa, bernyanyi, dan seremonialnya.

Perwujudan dan manifestasi komunikasi dalam pandangan ini bukanlah pada trasmisi/ pengiriman informasiinformasi intelijen namun diarahkan untuk konstruksi dan memelihara ketertiban, dunia budaya yang peneuh makna dimana dapat berperan sebagai alat kontrol dalam tindakan/pergaulan antar sesama manusia. Komunitas ideal diwujudkan dalam bentuk materi seperti tarian, permainan, arsitektur, kisah, dan penuturan. Penggunaan bahasa baik melalui artifisial maupun simbolik (sebagaimana nampak dalam wujud tarian, permainan, kisah, tutur lisan ) tidak ditujukan untuk kepentingan informasi tetapi untuk konfirmasi, juga tidak untuk merubah sikap atau pemikiran, tetapi untuk menggambarkan sesuatu yang dianggap penting oleh suatu komunitas, tidak untuk membentuk fungsi-fungsi tetapi untuk menunjukan sesuatu yang sedang berlangsung dan mudah pecah (fragile) dalam sebuah proses sosial. Persepektif ini kemudian memahami komunikasi sebagai suatu proses melaluimana budaya bersama diciptakan, diubah dan diganti. Dalam konteks antropologi, komunikasi 
berhubungan dengan ritual dan mitologi. Sedangkan dalam konteks sastra dan sejarah, komunikasi merupakan seni (art) dan sastra (literature). Komunikasi ritual pun tidak secara langsung ditujukan untuk menyebarluaskan informasi atau pengaruh tetapi untuk menciptakan, menghadirkan kembali, dan merayakan keyakinankeyakinan ilusif yang dimiliki bersama (Rothenbuhler, 1998).

Sedangkan simbol dan lambang didefinisikan Herosatoto (2008) sebagai suatu hal atau keadaan yang merupakan pengantar terhadap objek. Sementara itu Soubar (2003) memaknai simbol sebagai bentuk yang menandai sesuatu yang lain diluar perwujudan bentuk simbolik itu sendiri.

Lambang atau simbol adalah suatu yang digunakan untuk menunjukan sesuatu yang lainnya, berdasarkan kesepakatan sekelompok orang. Lambang meliputi katakata(pesan verbal), perilaku non verbal, dan objek yang maknanya disepakati bersama.

Menurut Hartoko dan Rahmanto (dalam Soubur, 2006), simbol dapat dibedahkan menjadi tiga macam, yaitu:

1. Simbol Universal, berkaitan dengan arketipos, tidur sebagai lambang kematian.

2. Simbol Kultural, yang dilatar belakangi oleh suatu kebudayaan tertentu (misalnya keris dalam kebudayaan jawa)

3. Simbol Individual, yang biasanya dapat ditafsirkan dalam konteks keseluruhan karya seorang pengarang.

Adapun sifat-sifat simbol adalah:

Lambang atau simbol bersifat
sembarangan, mana suka, atau
sewenang-wenang. Seperti diungkapkan oleh Pierce (Sobur, 2003), simbol diartikan sebagai tanda yang mengacu pada objek tertentu diluar tanda itu sendiri. Hal ini memperhatikan bahwa simbol bersifat sembarang, manusia dengan bebasnya memakai sesuatu dan menjadikannya sebagai simbol.

Lambang atau simbol pada dasarnya tidak mempunyai makna: manusialah yang memberi makna pada lambang.
Peran manusia dalam memaknai simbol dikemukakan oleh Leslie White (dalam Narwoko dan Suryanto, 2006), maka suatu simbol hanya dapat ditangkap melalui caracara nonsensoris yakni melalui proses penafsiran. Sebenarnya ada dalam kepala manusia, bukan pada lambang itu sendiri. Kalaupun ada orang yang mengatakan bahwa kata-kata mempunyai makna, yang iya maksud sebenarnya bahwa kata-kata itu mendorong orang untuk memberi makna (yang telah disetujui bersama) terhadap kata-kata itu.

Persoalan akan timbul bila para peserta komunikasi tidak memberi makna yang sama pada satu kata. Pemaknaan pesan yang berbeda akan menimbulkan kesalahan dalam berkomunikasi.

\section{Lambang atau simbol itu bervariasi.}

Lambang atau simbol bervariasi dari suatu budaya kebudaya lain, dari suatu tempat ketempat yang lain, dari suatu konteks satu kekonteks waktu lain. Begitu juga makna yang diberikan pada lambang tersebut. Akan tetapi, makna yang diberikan kepada suatu lambang boleh jadi berubahdalam perjalanan waktu.

\section{Simbol dan Budaya}

Manusia adalah mahluk budaya, dan budaya adalah manusia penuh simbolsimbol, sehingga dapat dikatakan bahwa manusia budaya manusia penuh diwarnai dengan simbolisme, yaitu suatu tata pemikiran menekankan atau mengikuti pola-pola berdasarkan diri kepada simbolsimbol ( Heusatoto, 2008).

Sepanjang sejarah kebudayaan manusia, simbol-simbol telah menjadi bagian dari kehidupan mereka sebagai mahluk yang berbudaya. Simbol tersebut tertuang dalam tingkah laku, bahasa, ilmu pengetahuan, relegi ataupun tradisi yang mereka tanamkan dalam masyarakat. Oleh karena itu lambang atau simbol sangat penting dalam berkomunikasi, karena berkat kemampuan menggunakan lambang, baik dalam penyandian maupun penyandian balik, manusia dapat berbagi pengalaman dan pengetahuan, bukan hanya pada 
mereka yang sama-sama hadir, bahkan juga antara mereka yang tinggal berjauhan, dan tidak pernah saling bertemu, antara pihakpihak yang berbeda generasi.

\section{Kebudayaan}

Disebutkan Kuswono (2008) kebudayaan mencakup semua hal yang dimiliki bersama oleh suatu masyarakat. Suatu kebudayaan mengandung semua pola kebiasaan-kebiasaan suatu masyarakat, seperti dalam bidang ekonomi, religi, hukum, kesenian, dan sebagainya.

Kebudayaan sangat berarti banyak bagi masyarakat dan individu-individu didalamnya, karena kebudayaan mengajarka manusia untuk hidup selaras dengan alam, sekaligus memberikan tuntunan untuk beraksi dengan sesamanya. Kebudayaan dan relegi juga merupakan dua hal yang tidak dapat dipisahkan begitu saja, terkadang kebudayaan merefleksikan tata cara beribadah dalam kepercayaan yang dianut manusia.

Beberapa ahli Antropologi terkenal seperti C. Wissler, C. Kluckhohn, A. Davis, atau A. Hoebel menganggap bahwa kebudayaan dan tindakan kebudayaan itu adalah segala tindakan yang harus dibiasakan oleh manusia dengan belajar (Koentjaranningrat, 2009). Sedemikiannya tak terpisahkan hubungan antara manusia dengan kebudayaan, sampai ia disebut mahluk yang berbudaya. Kebudayaan sendiri terdiri atas gagasan-gagasan, simbol-simbol, dan nilai-nilai sebagai hasil karya dan tindakan manusia. Manusia berpikir, bernafas, dan bersikap dengan ungkapan-ungkapan yang simbolis (Sobur, 2006).

Menurut Clifford Greertz (Sobur, 2006), kebudayaan adalah sebuah pola dari makna-makna yang tertuang dalam simbolsimbol yang diwariskan melalui sejarah. Kebudayaan adalah sebuah sistem dari konsep-konsep yang diwariskan dan diungkapkan dalam bentuk-bentuk simbolik melalui mana manusia berkomunikasi, mengekalkan dan memperkembangkan pengetahuan tentang kehidupan ini.
Menurut

Koentjaraningrat kebudayaan memiliki tiga wujud, yaitu:

1. Wujud kebudayaan sebagai suatu konteks dari ide, gagasan, nilai, norma, peraturan dan sebagainya, wujud kebudayaan yang pertama ini adalah wujud ideal dari kebudayaan. Sifatnya adalah abstrak, tidak dapat diraba atau difoto. Lokasi ada didalam kepala atau dalam alam pikiran warga masyarakat tempat kebudayaan bersangkutan itu hidup.

2. Wujud kebudayaan sebagai suatu kompleks aktivitas serta tindakan berpola dari manusia dalam masyarakat. Wujud kedua dalam kebudayaan ini disebut sistem sosial atau social system. Mengenai tindakan berpola dari manusia itu sendiri, yang terdiri dari aktivitas manusia berinteraksi, berhubungan, dan bergaul satu sama lain.

3. Wujud kebudayaan sebagai benda-benda hasil karya manusia. Wujud ketiga dari kebudayaan tersebut kebudayan fisik. Berupa seluruh hasil fisik dan aktivitas, perbuatan, dan karya semua manusia dalam masyarakat. Sifatnya paling kongkret dan merupakan benda-benda dan hal-hal yang dapat diraba, dilihat dan difoto.

Effendy (dalam Kuswaro, 2008) kemampuan manusia dalam membangun tradisi budaya, menciptakan tentang pemahaman realita yang diungkap secara simbolik, dan mewariskannya kepada generasi penerusnya, sangat tergantung pada bahasa.

C.Kluckhon menguraikan tujuh unsur kebudayaan yang dimaksud sebagai berikut:

1. Bahasa

2. Sitem pengetahuan

3. Organisasi sosial

4. Sistem peralatan hidup

5. Sistem mata pencarian hidup

6. Sistem relegi

7. Kesenian

Unsur-unsur kebudayaan ini yang digunakan untuk mempelajari suatu kebudayaan, dan memisahkan antara satu 
kebudayaan dengan kebudayaan lainnya. Kebudayaan ditinjau dari struktur dan tingkatannya. Berikut adalah penjelasannya:

1. Superculture, adalah kebudayan yang berlaku bagi seluruh masyarakat. Contohnya: kebudayan nasional;

2. Culture, lebih khusus, misalnya berdasarkan golongan etnik, profesi, wilayah atau daerah. Contohnya: kebudayan Sunda;

3. Subculture, merupakan kebudayan khusus dalam sebua culture, namun kebudayaan ini tidak lah bertentangan dengan kebudayaan induknya. Contoh : budaya gotong royong;

4. Counter-culture, tingkatannya sama dengan sub-culture yaitu merupakan bagian turunan dari culture, namun counter-culture bertentangan dengan kebudayaan induknya. Contoh: kebudayaan Individualisme.

Dilihat dari struktur dan tingkatannya budaya lokal berada pada tingkat culture. Hal ini berdasarkan sebuah skema sosial budaya yang ada diindonesia dimana terdiri dari masyarakat yang bersifat majemuk dalam struktur sosial, budaya (multikultural) maupun ekonomi. Jacobus Ranjabar (2006) mengatakan bahwa dilihat dari sifat majemuk masyarakat indonesia, maka harus diterima bahwa ada tiga golongan kebudayaan yang masing-masing mempunyai coraknya sendiri, ketiga golorang tersebut adalah sebagai berikut:

1. Kebudayaan suku bangsa ( yang lebih dikenal secara umum di indonesia dengan nama kebudayaan daerah)

2. Kebudayaan umum lokal

3. Kebudayaan nasional

Dalam penjelasanya, kebudayaan suku bangsa adalah sama dengan budaya lokal atau budaya daerah. Sedangkan kebudayaan umum lokal adalah tergantung aspek ruang, biasanya ini bisa dianalisis pada ruang perkotaan dimana hadir berbagai budaya lokal atau daerah yang dibawah oleh setiap pendatang, namun ada budaya dominan yang berkembang yaitu misalnya budaya lokal yang ada dikota atau tempat tersebut. Sedangkan kebudayaan nasional adalah akumulasi dari kebudayaan-kebudayaan daerah.

Definisi Jacobus itu seirama dengan pandangan Koerntjaraningrat (2000). Koentjaraningrat memandang budaya lokal terkait dengan istilah suku bangsa, dimana menurutnya, suku bangsa sendiri adalah suatu golongan manusia yang terikat oleh kesadaran dan identitas akan 'kesatuan kebudayaan'. Dalam hal ini unsur bahasa adalah ciri khasnya. Pandangan yang menyatakan bahwa budaya lokal adalah merupakan bagian dari sebuah skema dari tingkatan budaya (hierakis bukan berdasarkan baik dan buruk), dikemukakan oleh antropolog terkemuka di indonesia yang beretnis sunda, Judistira K. Garna. Menurut judistira (2008), kebudayaan lokal adalah melengkapi kebudayaan regional, dan kebudayan regional adalah bagianbagian yang hakiki dalam bentukan kebudayaan nasional.

Dari hasil penelitian di lapangan, di dapat hasil Dalam ritual Tabot ada sembilan langkah yaitu:

1) Mengambik tanah, istilah mengambik tanah dalam tradisi tabot adalah peringatan atau mengenang kembali asal kejadian manusia yang diciptakan dari tanah kemudian kembali lagi ketanah.

2) Duduk penja (mencuci jari-jari), istilah duduk penja dalam tradisi tabot adalah simbol mengajak umat agar selalu menyucikan diri yang di awali dari kedua tangan karena tangganlah yang dapat membuat menjadi kotor dan tangan pulalah yang dapat membuat kita menjadi bersih baik lahir maupun batin.

3) Menjara, istilah menjara dalam tradisi tabot adalah perjalanan panjang dimalam hari dengan arak-arakan dol, bendera,dan panji-panji kebesaran yang diibaratkan ketika akan terjadi perang kerbala.

4) Meradai (mengumpulkan dana),istilah meradai dalam tradisi tabot adalah bermakna upaya untuk membangkitkan emansipasi masyarakat dalam bentuk : 
beras, gula, minuman, uang, atau lainnya agar trasa saling memiliki seni budaya tabot karbala yang harus dilestarikan.

5) Arak Penja (mengarak jari-jari), istilah arak penja dalam tradisi tabot adalah sebagai simbol lima hurup sang pencipta, simboli marukun, dan simbol penghormatan kepada alhusein sebagai raja para suhada di padang karbala.

6) Arak Serban (mengarak surban), istilah arak serban dalam tradisi tabot adalah asesoris yang dipakai sebagai ikat dan penutup kepala mahkota kehormatan iman khusein yang diriwatakan disita atau didalam tas oleh akmas bin mitsat, setelah mencuri barang khusein, akmas bin mitsat menjadi gila.

7) Gam (tenang berkabung), istilah gam dalam tradisi tabot adalah merupakan tradisi hari bersedih yang diperingati setiap tanggal 9 muharam dimaksudkan untuk merenung, mengapa alhusein harus dibunuh dengan cara menyiksa, atas perbuatan biadab yazin bin muawiyah.

8) Arak Gedang (taptu akbar), istilah arak gendang dalam tradisi tabot bebrarti sebutan malam puncak prosesi ritual budaya tabot pada arena utama yang sekaligus sebagai penutupan secara resmi pestival yang diselengarakan oleh dinas kebudayaan dan pariwisata.

9) Tabot Terbuang, istilah tabot terbuang dalam tradisi tabot adalah sebuah ekspresi membuang keburukan ,membuang kesombongan, dan klimaknya membuang kebiadapan. Serta mengenang said dipadang karbala.

\section{PENUTUP}

\section{Kesimpulan}

Upacara tabot diprovinsi bengkulu merupakan tradisi yang turun temurun dilaksanakan dan menjadi aset daerah. Upacara ini dilakukan dengan sembilan ritual, dimana masing-masing ritual sarat dengan pesan dan makna yang mengandung arti dan menceritakan sebuah sejarah atau kisah.

\section{Saran}

Saran yang dapat diberikan dalam penelitian ini adalah setiap upacara tabot setiap keturunan tabot harus melaksanakan kegiatan perayaan tersebut dengan lebih hikmat.

\section{DAFTAR PUSTAKA}

Effendy, Onong Uchjana. (2008). Dinamika Komunikasi. Bandung: PT Remaja Rosdakarya.

Effendy, Onong Uchjana. (2008). Ilmu Komunikasi Teori dan Praktek. Bandung: PT Remaja Rosdakarya.

Kriyantono, Racmat. (2006). Teknik Praktis

Riset Komunikasi Jakarta: PT Prenada Media Group.

Koentjaraningrat. (2007). Manusia dan Budaya di Indonesia. Jakarta: Djambatan.

Koentjaraningrat. (2009). Pengantar Ilmu Antrapologi. Jakarta: PT. Rineka Cipta.

Kuswarno, Engkus. (2008). Etnografi Komunikasi. Bandung: Widya Padjadjaran.

Mulyana, Deddy. (2005). Komunikasi Efektif. Bandung: PT Remaja Rosdakarya.

Mulyana, Deddy. (2009). Ilmu komunikasi Suatu Pengantar. Bandung: PT Remaja Rosdakarya.

Mulyana, Deddy. (2006). Metodologi Penelitian Kualitatif. Bandung: PT Remaja Rosdakarya.

Rakhmat, Jalaludin. (2005). Psikologi Komunikasi. Bandung: PT Remaja Rosdakarya.

Sobur, Alex. (2006). Semiotika Komunikasi. Bandung: Rosdakarya.

Sugiyono. (2007). MetodePenelitian Kuantitatif dan Kualitatif dan $R$ dan D. Bandung: Alfabeta. 